\title{
Implementasi Alokasi Dana Desa dalam Pemberdayaan Masyarakat Di Desa Mudung Darat Kecamatan Maro Sebo Kabupaten Muaro Jambi
}

\author{
Masriyani $^{1}$, Hisbah $^{2}$, Feri Setiawan $^{3}$ \\ Fakultas Hukum, Universitas Batanghari Jambi, Indonesia \\ Jl. Untung Suropati Rt.44 Jelutung, Kota Jambi, Indonesia \\ Correspondence email:masriyani@unbari.ac.id, email: hisbah@unbari.ac.id
}

\begin{abstract}
Abstrak. Sesuai hasil observasi di desa Mudung Darat Kecamatan Maro Sebo Kabupaten Muaro Jambi, pengelolaan dana desa, terutama Alokasi Dana Desa ini belum terlaksana secara optimal, terutama pada tahap perencanaan dan pelaksanaan alokasi dana desa tersebut. Penelitian ini memiliki tujuan untuk mengetahui dan menganalisis Implementasi Alokasi Dana Desa Dalam Pemberdayaan Masyarakat Di Desa Mudung Darat Kabupaten Muaro Jambi, untuk mengetahui dan menganalisis kendala Implementasi Alokasi Dana Desa Dalam Pemberdayaan Masyarakat Di Desa Mudung Darat Kabupaten Muaro Jambi dan untuk mengetahui dan menganalisis upaya mengatasi kendala Implementasi Alokasi Dana Desa Dalam Pemberdayaan Masyarakat Di Desa Mudung Darat Kabupaten Muaro Jambi. Jenis penelitian yang dipergunakan pada penelitian ini ialah penelitian yuridis empiris. Adapun bahan hukum yang dipergunakan meliputi bahan hukum primer berupa UU Nomor 6 Tahun 2014 dan Paraturan Bupati Muaro Jambi No.08 Tahun 2016, bahan hukum sekunder terdiri bahan pustaka , kamus, dan artikel yang berhubungan dengan pembahasan, dengan menggunakan metode pengumpulan berupa studi lapangan dan studi pustaka yang selanjutnya di analisis dengan metode deduktif. Dalam hasil penelitian didapatkan gambaran bahwa implementasi ADD dalam menjalankan Belanja Publik dan Pemberdayaan masyarakat belum terlaksana dengan optimal. Kendala yang dihadapi dalam pengimplementasian alokasi yaitu kurangnya pemahaman aparat Pemerintah Desa mengenai tugas pokok dan fungsi serta masih kurangnya penyampaian informasi dan sosialisai kepada masyarakat. Kualitas Sumber Daya Manusia (SDM) Yang Belum Mendukung Pengelolaan Dan Pelaksanaan Alokasi Dana Desa.
\end{abstract}

Kata Kunci: implementasi, Alokasi Dana Desa, pemberdayaan

Abstract. According to the results of observations made by the author in the village of Mudung Darat, Maro Sebo District, Muaro Jambi Regency, the management of village funds, especially the Village Fund Allocation, has not been implemented optimally, especially in the planning and implementation stages of the village fund allocation. This study aims to determine and analyze the Implementation of Village Fund Allocation in Community Empowerment in Mudung Darat Village, Muaro Jambi Regency, to identify and analyze the constraints of Village Fund Allocation Implementation in Community Empowerment in Mudung Darat Village, Muaro Jambi Regency and to identify and analyze the efforts made to overcome the obstacles in implementing Village Fund Allocation in Community Empowerment in Mudung Darat Village, Muaro Regency. This type of research used in this paper is empirical juridical research. The implementation of ADD in carrying out Public Expenditures and community empowerment has not been carried out optimally. The obstacles faced in implementing the allocation are the lack of understanding of the Village Government apparatus regarding the main tasks and functions and the lack of information and socialization to the community. Quality of Human Resources (HR) That Has Not Supported the Management and Implementation of Village Fund Allocation. The culture of mutual cooperation among the people of Mudung Darat Village is starting to fade, and the culture of mutual cooperation is the hallmark of a village.

Keywords: implementation, Village Fund Allocation, empowerment

\section{PENDAHULUAN}

Undang-Undang mengenai Desa sudah memposisikan desa sebagai salah satu faktor dalam membangun dan meningkatkan kesejahteraan penduduknya. Desa diberi sumber dana serta wewenang yang mumpuni supaya mampu memanajemen sumber daya yang ada untuk mengembangkan kesejahteraan penduduk serta meningkatkan taraf perekonomian. Di tiap tahunnya, aparat pemerintahan sudah memberikan anggaran dana yang cukup tinggi guna membangun serta meningkatkan Desa. Pembangunan nasional memiliki tujuan membentuk masyarakat yang makmur dan adil yakni dengan cara spiritual dan material yang berpedoman terhadap UUD Republik Indonesia dan Pancasila. Sebgai wujud penerapan Pancasila, pembangunan nasional wajib dilaksanakan di seluruh unsur kehidupan berbangsa dan bernegara yang dilaksanakan masyarakat secara kolektif bersama pemerintah. Supaya kegiatan pemerintah dan masyarakat bisa diselenggarakan, tentunya masyarakat selaku tokoh utama pembangunan harus dilindungi, diarahkan,

\footnotetext{
${ }^{1}$ Masriyani, Dosen Tetap Yayasan Pendidikan Jambi, Universitas Batanghari, Program Studi Ilmu Hukum

${ }^{2}$ Hisbah, Dosen Tetap Yayasan Pendidikan Jambi, Universitas Batanghari, Program Studi Ilmu Hukum

${ }^{3}$ Feri Setiawan, Mahasiswa Fakultas Hukum Universitas Batanghari Program Studi Ilmu Hukum
} 
dan dibimbing pemerintah supaya tujuan pembangunan nasional bisa diwujudkan melalui dukungan dari pemerintah dan masyarakat. ${ }^{4}$

Di Indonesia, pada dasarnya desa bisa dinyatakan sebagai suatu daerah paling kecil yang diatur dengan cara mandiri dan formal dari kelompok masyarakat di dalamnya terdapat peraturan-peraturan yang disepakati di mana bertujuan meningkatkan kesejahteraan, keteraturan, dan kebahagiaan yang dinilai merupakan pertanggungjawaban dan hak bersama kelompok masyarakatnya itu. ${ }^{5}$

Di tahun 2015, desa diberi anggaran dana senilai Rp20,7 triliun, yang rata- ratanya kebanyakan daerah memperoleh anggaran desa mendapatkan dana sebanyak Rp280 juta. Kemudian di tahun berikutnya, anggaran mengalami peningkatan jadi sebanyak Rp46,98 triliun yang rata-ratanya tiap daerah diberi sebanyak Rp628 juta, lalu di tahun 2017 mengalami peningkatan lagi jadi sebanyak Rp 60 Triliun yang tiap-tiap desanya diberi sebanyak Rp800 juta. Sesuai dengan data-data tersebut, anggaran yang diberi tersebut mampu dibuktikan sudah memperoleh fasilitas yang berguna untuk rakyat, yakni contohnya membangun jalan desa melebihi 95,2 ribu $\mathrm{km}$, jembatan sepanjang $914.000 \mathrm{~m}$, tambatan perahun sebanyak 2201 unit, PAUD sebanyak 14.957 unit, sambungan air bersih sebanyak 22.616 unit, polindes sejumlah 4.004 unit, pasar desa sejumlah 3.106 unit, Posyandu sejumlah 10.964 unit, embung sebanyak 1.338 unit, irigasi dan drainase sebanyak 103.405 unit, serta sumur sebanyak 19.485 unit pada kurun waktu 2015 hingga $2016 .{ }^{6}$

Di samping hal tersebut, daerah desa pun memiliki peluang dalam meningkatkan perekonomian masyarakatnya dengan adanya pemasaran kerajinan rakyat, pelatihan, mengembangkan kawasan wisata dengan adanya badan usaha milik desa (BUMDes), serta mengembangkan usaha perikanan dan peternakan. Tolak ukur dalam meningkatkan kesejahteraan terhadap pembangunan desa ialah dengan menguatkan kerja sama, kreasi, inisiasi, serta inovasi terhadap masyarakatnya untuk mencapai tujuan yang diinginkan. Dalam membangun daerah desa, tentunya pihak yang berewenang tidak bisa melakukannya dengan mandiri, tetapi membutuhkan prakarsa dukungan, serta peran aktif masyarakatnya.

Berdasarkan data yang sudah diperoleh, diketahui bahwasannya pada dua tahun terakhir anggaran yang digunakan memperlihatkan bahwasannya dana tersebut sudah terbukti dapat membuat kualitas hidup masyarakatnya menjadi meningkat. Adapun hal itu dapat diketahui bahwa terjadi penurunan jumlah penduduk miskin desa yang awalnya 17,7 juta di tahun 2014 jadi 17,1 juta di tahun 2017. Selain itu juga terjadi penurunan pada rasio ketimpangan pada desa yang awalnya 0,34 di tahun 2014 jadi 0,32 di tahun 2017. Persentase penduduk miskin yang menurun juga merupakan tanda terhadap keberhasilan tersebut, yakni yang awalnya 14,09\% di tahun 2015 jadi 13,93\% pada tahun 2017. ${ }^{7}$

Keberhasilan tersebut juga bisa lagi meningkat untuk ke depannya yakni jika mampu mengelola anggaran yang diberikan secara tepat. Aspek utama yang bisa diimplementasikan untuk mengelola anggaran untuk ialah mengaitkan masyarakatnya ialah diperlukan adanya pemanfaat bahan baku lokan yang tersedia, memakai tenaga kerja sekitar, serta melaksanakan aktivitas melalui pola swakelola. Melalui pelasaksanaan pola tersebut, dengan demikian dibuat rencana serta implementasi yang dapat dilaksanakan sendiri oleh daerahnya. Dengan demikian anggaran yang dipakai dalam membangun itu juga akan tersalu juga pada masyarakatnya. Melalui penggunaan tenaga kerja warga sekitar, diinginkan aktivitas yang dilaksanakn itu dapat memberi penghasilan untuk masyarakatnya. Sedangkan dalam penggunaan bahan baku local diinginkan bisa memberi pendapatan terhadap masyarakatnya yang mempunyai bahan tersebut.

Pada saat sekarang, peran aparat daerah tentunya ditbutukan untuk mendukung seluruh aktivitas untuk membangun desa. Sejumlah upaya yang direncanakan telah dilaksanakan aparat Desa. Supaya bisa melaksanakan tugasnya dengan efisien serta efektif, aparat daerah harus selalu berkembang berdasarkan masyarakat serta lingkungannya yang juga berkembang maju. Dalam hal ini terjadi perubahan sosial yang diakibatkan terdapatnya program dalam membangun desa yang disertai juga kapasitas pemerintah desa yang dikembangkan. Dengan demikian, masyarakat serta desanya bukan cuma sekadar berperan selaku objeknya, namun bisa menempatkan dirinya selaku subjek yang ikut membangun.

Berhubungan pada hal itu, upaya dalam mengembangkan pengetahuan serta wawasan untuk pelaksana pembangunannya menjadi prioritas utama yang perlu diperhatikan. Peran aparat daerah sungguh diperlukan pada sejumlah faktor kehidupannya. Perhatian pemerintah desa dan inovasi pada sejumlah fasilitas pun tentunya dibutuhkan

${ }^{4}$ M. Muslih, Masriyani dan Ryanda Putra Pratama, Pelaksanaan Program Badan Usaha Milik Desa (BUMDes) Di Kecamatan Jambi Luar Kota Kabupaten Muaro Jambi, Jurnal Wajah Hukum, Universitas Batanghari, Volume 4, Nomor 2, Oktober 2020.

${ }^{5}$ Jefri S.Pakaya, Pemberian Kewenangan Pada Desa Dalam Konteks Otonomi Daerah, Jurnal Legislasi Indonesia, Volume 13 Nomor 01, 2016.

${ }^{6}$ Kementrian Keuangan, Buku Saku Dana Desa, Direktorat Jenderal Kementerian Keuangan, Jakarta, 2017, hal.ii

${ }^{7}$ Ibid., 
untuk terciptanya desa yang sejahtera. Selanjutnya, dampak rasional terdapatnya tuntutan serta wewenang terhadap penyeleggaraan desa yang otonom ialah terdapatnya anggaran yang cukup, menyebutkan bahwasannya: Keuangan ataupun pembiayaan menjadi aspek utama untuk mendorong pelaksanaan desa yang otonom, sama seperti dalam menyelenggarakan otonomi daerah yang menyebutkan bahwasannya "autonomy" berkaitan terhadap "auto money", dengan demikian dalam mengurus serta mengatur daerahnya, pemerintah memerlukan biaya ataupun anggaran yang cukup untuk melaksanakan wewenang yang diberikan. ${ }^{8}$

Berdasarkan Pasal 1 ayat 1 UU Republik Indonesia Tahun 2014 No.6 Tentang Desa, disebutkan bahwa: Merupakan suatu integral warga hukum yang mempunyai batasan wilayah dan wewenang dalam mengurus serta mengatur rumah tangga daerahnya, peran masyarakat sekitar sesuai dengan prakarsanya, hak tradisional serta hak asal usul, yang dihormati serta diakui pada sistem pemerintahan NKRI.

Pelaksanaan yang mendorong untuk wewenang itu, pada UU Tahun 2014 No. 6, daerah diberi anggaran yang diperoleh berdasarkan 7 sumber, yakni antara lain:

1. Bagian dari PDRD (Pajak Daerah dan Retribusi Daerah) Kabupaten/kota, paling sedikit sebanyak 10\% dari hasil retribusi daerah kabupaten/kota serta pajak daerah;

2. Alokasi Dana Desa, yakni bagian dana perimbangan diterima kabupaten/kota di luar DAK (DBH dan DAU) sebanyak $10 \%$;

3. Anggaran dari APBD provinsi/kabupaten/kota;

4. Sumbangan serta hibah dan yang tidak terdapat keterikatan oleh pihak ketiga;

5. Pendapatan asli desa, mencakup swadaya, gotong royong hasil usaha, partisipasi hasil aset, serta lainnya;

6. Dana Desa (Alokasi APBN);

7. Pendapatan desa yang lainnya secara sah.

Kebijakan itu memberi amanat terhadap aparat Kabupaten dalam memberi alokasi anggaran untuk desa, yakni berupa ADD (Alokasi Dana Desa) melalui pertimbangan terwujudnya pemerataan serta prinsip keadilan. Alokasi Dana Desa merupakan anggaran yang diberikan untuk desa dari pemerintah kabupaten yang jumlahnya didapatkan dari pengurangan 10\% dari DAK (Dana Alokasi Khusus). ADD (Alokasi dana desa) menjadi perwujudan terhadap korelasi dana pada tingkatan-tingkatan pemerintah, yakni korelasi anggaran terhadap pemerintah desa dan pemerintah kabupaten. Agar bisa membuat rumusan yang selaras, dengan demikian dibutuhkan adanya pemahaman tentang wewenang yang ada pada aparat desa.

Hal itu berarti bahwa dana yang diberi untuk Desa keseluruhannya merupakan kebutuhan terhadap pemberdayaan desa serta sarana dan prasanan pembangunan selaku pemerintahan yang berjasa. Anggaran itu wajib dipakai serta dialokasikan seperti yang seharusnya berdasarkan ketentuan serta UU yang berjalan dan sudah disahkan negara. Dengan demikian ADD (Alokasi Dana Desa) itu dapat membuat desa menjadi sejahtera.

Desa memiliki peranan dalam mengatur serta mengurus yang berdasarkan kebijakan UU Tahun 2014 No. 6 mengenai Desa yang pada pasal-pasal di antaranya disebutkan bahwa Desa mempunyai wewenang untuk membangun, memberdayakan desa, membina masyarakat, serta menyelenggarakan pemerintahan. Dalam melaksanakan tugastugasnya, pemerintah desa diberi pekerjaan yang tidak muda dalam meninjau desa merupakan suatu hal yang langsung berkaitan pada masyarakat. Di zaman sekarang, peran aparat desa tentunya dibutuhkan untuk mendukung keseluruhan aspek dalam membangun daerahnya. Sejumlah upaya yang direncanakan telah dilaksanakan aparat desa. Supaya bisa melaksanakan tugasnya dengan efisien serta efektif, aparat daerah harus selalu berkembang berdasarkan masyarakat serta lingkungannya yang juga berkembang maju. Dalam hal ini terjadi perubahan sosial yang diakibatkan terdapatnya program dalam membangun desa yang disertai juga kapasitas pemerintah desa yang dikembangkan. Dengan demikian, masyarakat serta desanya bukan hanya sekadar berperan selaku objeknya, namun bisa menempatkan dirinya selaku subjek yang ikut membangun.

Peraturan Dana alokasi anggaran untuk desa berdasarkan kebijakan UU Tahun 2014 No. 6 Pasal 72 ayat (4), apabila wewenang itu tidak dilakukan, dengan demikian terdapat konsekuensi yang tercantum pada Pasal 72 ayat (6), di mana aparat bisa memotong alokasi Dana Perimbangan jika sudah dikurangkan DAK (Dana Alokasi Khusus) ataupun menundanya. Adapun tujuan Alokasi Dana Desa (ADD) ini antara lain:

1. Mendorong pemerataan kesempatan bekerja serta pendapatan untuk masyarakatnya;

2. Mendukung swadaya gotong royong yang meningkat pada masyarakat desa. Mendorong aparat desa untuk membangun serta melayani masyarakat berdasarkan wewenangnya.

3. Mengembangkan kaspasitas masyarakat desa untuk merencanakan, melaksanakan, serta mengendalikan kegiatan melalui kontribusinya berdasarkan peluang yang ada.

\footnotetext{
${ }^{8}$ Sadu Wasistiono dan Irwan Tahir. (2006). Prospek Pengembangan Desa. Jatinangor, hal. 107
} 
Dapat dipahami bahwa, dari pengelolaan dana desa tersebut adalah kemampuan kwalitas aparatur desa yang terlibat saat mengelola Alokasi Dana Desa, dan kontribusi masyarakatnya, khususnya pemuda yang mempunyai pemikiran, ide kritis dan inovatif merupakan hal yang penting agar pembangunan dan kemajuan desa dapat tercapai sesuai tujuannya otonomi desa itu sendiri. Salah satu desa yang menerima ADD (Alokasi Dana Desa) oleh pemda ialah desa Mudung Darat di Kec. Maro Sebo, Kab. Muaro Jambi. Untuk mengelola ADD yang diperoleh, kemudian diberikan kepada Kab. Muaro Jambi, berdasarkan Paraturan Bupati Muaro Jambi No.08 Tahun 2016, Pasal 8 dijelaskan bahwa:

ADD yang diterima oleh Desa dipergunakan untuk belanja kegiatan bidang pemberdayaan masyarakat desa, penyelenggaraan pembangunan, serta pembinaan masyarakat. Belanja bidang penyelenggaraan pemerintahan desa seperti yang terdapat dalam ayat (1) terlebih dahulu memperhitungkan kebutuhan: operasional BPD; tunjangan BPD operasional pemerintahan desa ; penghasilan tetap perangkat desa serta kepala desa ; operasional RT; dan tunjangan perangkat desa serta kepala desa.

Berdasarkan pengamatan yang dilakukan, pada desa Mudung Darat Kec. Maro Sebo Kab. Muaro Jambi, pengelolaan dana desa, terutama Alokasi Dana Desa ini belum terlaksana secara optimal, terutama pada tahap perencanaan serta implementasi anggaran yang diberikan. Karena belum melibatkan masyarakat terutama pemuda pemudi yang sangat diharapkan terlibat agar tercapainya kemajuan desa. Oleh karena melihat pasal 8 ayat (1) Peraturan Bupati Muaro Jambi Nomor 8 Tahun 2016, yang telah menyatakan bahwa ADD yang diberikan dapat juga dipergunakan untuk membangun desa, membina masyarakat, serta memberdayakan masyarakatnya. Dengan di kaitkan pada tujuan dari pemberian ADD itu sendiri. Sesuai dengan latar belakang yang dijelaskan sebelumnya, adapun rumusan masalah pada penelitian ini sebagai berikut: (1) Bagaimana Implementasi Alokasi Dana Desa Di Desa Mudung Darat Kabupaten Muaro Jambi? (2) Apakah yang menjadi kendala dalam Implementasi Alokasi Dana Desa Di Desa Mudung Darat Kabupaten Muaro Jambi?

\section{METODE}

\section{Jenis dan Pendekatan Penelitian}

Tipe penelitian yang dipergunakan pada penulisan ini ialah penelitian yuridis empiris. Dalam pendekatan penelitian ini ditujukan guna memahami seberapa jauh efektifitas penerapan hukum pada lingkungan kemasyarakatan, sehingga dapat dikatakan untuk mengetahui kesenjangan antara das sollen dengan das sein.

Berdasarkan pendapat Sri Mamuji serta Soerjono Soekanto, penelitian yuridis empiris merupakan: "penelitian hukum yang dilaksanakan melalui penelitian data primer". ${ }^{9}$ Sedangkan menurut Peter Mahmud Marzuki Penelitian yuridis empiris disebut juga socio legal research (penelitian sosio legal) yaitu:

Penelitian sosio legal hanya memposisikan hukum sebagai fenomena sosial. Berdasarkan hal itu, hukum dilihat berdasarkan sisi luar saja. Maka dari itu, pada penelitian sosio legal, hukum biasanya dihubungkan pada persoalan sosial. Maka pada penelitian sosio legal ialah penelitian yang memfokuskan pada tindakan masyarakat ataupun personal yang berhubungan terhadap hukum. ${ }^{10}$

Sesuai dengan penjelasan itu di atas maka bisa ditarik kesimpulan bahwa penelitian hukum yuridis empiris merupakan penelitian hukum yang menganalisis serta mengkaji mengenai tingkah laku masyarakat ataupun individu yang berkaitan terhadap melalui sumber data primer.

\section{Sumber Data dan Bahan Hukum \\ Penelitian Lapangan}

Penelitian lapangan dilaksanakan melalui wawancara langsung pada responden dengan pertanyaan yang sudah dipersiapkan sebelumnya. Kegiatan tersebut bertujuan dalam mendapatkan data yang akurat serta tepat berdasarkan sumber yang ditentukan terdahulu. Pada kegiatan itu, seluruh jawaban ataupun keterangan yang didapatkan tentang suatu hal yang dikehendaki harus direkam ataupun dicatat.

\section{Penelitian Kepustakaan}

Penelitian kepustakaan dilaksanakan menggunakan metode pengumpulan data studi dokumen yaitu dengan mencari data serta informasi berkaitan dengan permasalahan penelitian melalui buku, jurnal, karya ilmiah maupun penelitian lainnya yang berhubungan terhadap masalah yang akan diamati.

${ }^{9}$ Soerjono Soekanto dan Mamuji Sri, Penelitian Hukum Normatif Suatu Tinjauan Singkat, Raja Grafindo Persada, Jakarta, 2010, hal. 14. Dalam buku Salim HS, Erlies Septiana Nurbaini, Penerapan Teori Hukum Pada Penelitian Tesis dan Disertasi, Cetakan ke-4, Raja Grafindo Persada, Jakarta, 2016, hal. 20.

${ }^{10}$ Peter Mahmud Marzuki, Penelitian Hukum, Kencana, Jakarta, 2009, hal. 87. Dalam buku Salim HS, Erlies Septiana Nurbaini, Penerapan Teori Hukum Pada Penelitian Tesis dan Disertasi, Cetakan ke-4, Raja Grafindo, Jakarta, 2016, hal. 20. 


\section{Metode Analisis Data}

Pengolahan data dilaksanakan melalui pengumpulan data, yakni data sekunder ataupun data primer diklasifikasikan dan diseleksi secara yuridis, kemudian dianalisis secara kualitatif. Analisis secara kualitatif adalah: "analisis data yang tidak menggunakan angka, namun memberi deskripsi-deskripsi (gambaran) berupa kata-kata terhadap penemuan-penemuan, dan karena hal itu dirinya cenderung mendahulukan kualitas ataupun mutu terhadap datanya".

\section{Tinjauan Pustaka \\ Pengaturan Pemerintah Desa}

Sesuai dengan Undang-Undang RI Tahun 2014 No. 6 tentang Desa, pemerintahan desa merupakan penyelenggaraan kepentingan masyarakat setempat dan urusan pemerintahan setempat pada sistem pemerintahan NKRI. Sementara pemerintah desa ialah kepala desa ataupun yang secara umum dikatakan dibantu perangkat desa sebagai pihak pelaksana pemerintah desa. Dengan adanya UU RI Tahun 2014 No. 6 tentang Desa, Pasal 1 ayat (3), dapat dimaknai bahwasannya pemerintah desa ialah kepala desa dan perangkat desa sebagai pihak pelaksana pemerintahan desa.

Kemudian, berdasarkan Peraturan Menteri Desa RI Tahun 2017 No. 19 tentang Penetapan Prioritas Penggunaan Dana Desa Tahun 2017, Pasal 1 Ayat 6 dan Ayat 7, pemerintah desa ialah kepala desa ataupun yang secara umum dibantu perangkat desa sebagai pihak pelaksana pemerintahan desa. Sementara pemerintahan desa merupakan pelaksanaan kepentingan masyarakat setempat dan urusan pemerintahan setempat pada sistem pemerintahan NKRI.

Undang-Undang Tahun 2014 No. 6 tentang Desa Pasal 18 menjelaskan bahwa, kewenangan desa mencakup wewenang pada segi pelaksanaan pemerintahan desa, pemberdayaan masyarakat desa, dan pelaksanaan pembangunan desa sesuai adat istiadat desa, prakarsa masyarakat, dan hak asal usul. Berikutnya dalam Pasal 19 dijelaskan "Wewenang Desa mencakup: wewenang sesuai hak asal usul; wewenang lokal berskala desa; wewenang yang diberikan pemerintah, pemerintah daerah kabupaten/kota, ataupun pemerintah daerah provinsi".

\section{Asas dan Tahap Pengelolaan Keuangan Desa}

Keuangan Desa diatur sesuai dengan praktek-praktek pemerintahan secara efektif. Pengelolaan Keuangan Desa berpedoman pada asas pasrtisipatif, transparansi, dan akuntabel, partisipatif dan dilaksanakan secara disiplin dan tertib anggaran (Peraturan Kementerian Dalam Negeri) Tahun 2014 Nomor 113 mengenai Pengelolaan Keuangan Desa, yang dipaparkan sebagai berikut:

1. Transparansi adalah prinsip keterbukaan yang memberi kemungkinan pada masyarakat dalam mendapat dan mengetahui akses informasi sangat luas mengenai keuangan desa. Asas yang membukakan dirinya pada hak masyarakat dalam mendapatkan informasi yang tidak diskriminatif, benar, dan jujur mengenai penyelenggaraan pemerintahan desa yang senantiasa memerhatikan kebijakan peraturan perundang-undangan;

2. Akuntabel adalah mewujudkan kewajiban dalam bertanggungjawab terhadap penyelenggaraan kebijakan yang diyakini untuk mencapai suatu hal yang ditetapkan dan bertanggungjawab terhadap pengendalian dan pengelolaan sumber daya. Asas akuntabel menjadi penentu bahwa tiap-tiap aktivitas dan hasil akhir aktivitas pelaksanaan pemerintahan desa wajib bisa dipertanggungjawabkan pada masyarakat desa berdasarkan kebijakan peraturan perundang undangan;

3. Partisipatif adalah pelaksanaan pemerintahan desa dengan melibatkan unsur masyarakat desa dan lembaga desa;

4. Disiplin anggaran dan tertib dalam mengelola keuangan desa wajib mengarah terhadap pedoman ataupun aturan atau pedoman yang mendasarinya.

Siklus dalam mengelola keuangan desa mencakup perencanaan, pelaksanaan, penatausahaan, pelaporan, dan pertanggungjawaban, pada periode 1 tahun anggaran, dihitung tertanggal 1 Januari hingga 31 Desember. 


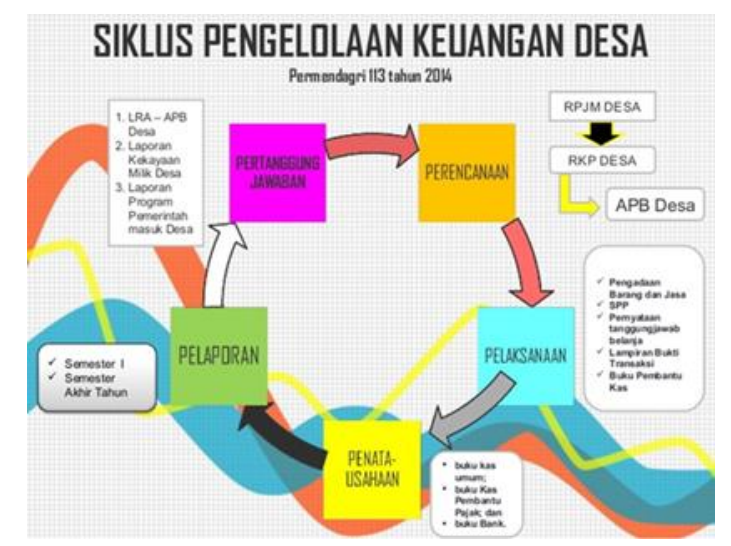

Gambaran Siklus Pengelolaan Keuangan Desa

Masing-masing tahap dalam mengelola keuangan desa itu mempunyai peraturan-peraturan yang wajib dilaksanakan dan dipahami berdasarkan batas-batas waktu yang sudah ditetapkan. Kegiatan dalam mengelola Keuangan Desa bisa dilakukan secara efektif tentu saja perlu ditunjang dengan adanya SDM yang berkualitas dan berkompeten dan diikuti prosedur dan sistem keuangan yang memadai.

Kegiatan dalam mengelola Keuangan Desa dikuasai Kepala Desa. Namun pada penyelenggarannya, kekuasaan itu sebagiannya dikuasai perangkat desa dengan demikian penyelenggaraan dalam mengelola keuangan dilakukan dengan cara kolektif oleh PTPKD (Pelaksana Teknis Pengelolaan Keuangan Desa) dan Kepala Desa. Ilustrasi Struktur Organisasi Pengelolaan Keuangan dalam pemerintahan desa dapat dideskripsikan sebagai berikut:

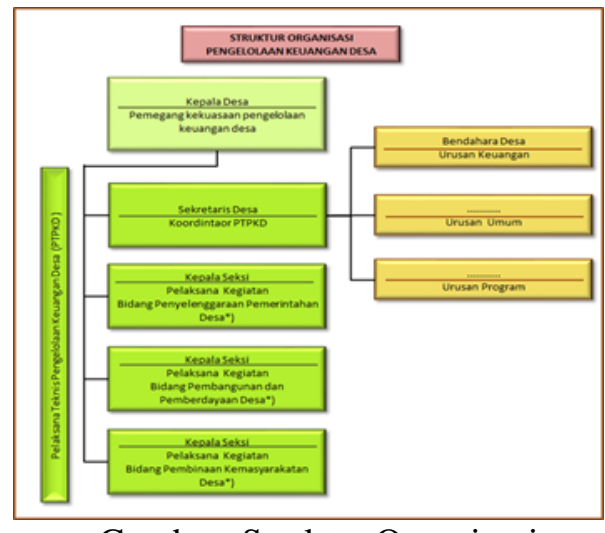

Gambar: Struktur Organisasi

Pengelolaan Keuangan Desa

Dengan demikian, pemerintah desa wajib mempunyai struktur organisasi pengelolaan keuangan, kriteria, bagan alir, dan uraian tugas yang merupakan tolak ukur pada aktivitas daam mengelola keuangan desa. Pada siklus pengelolaan keuangan desa, tugas dan tanggungjawab Kepala Desa dan PTPKD. Pelaksana Teknis Pengelolaan Keuangan Desa meliputi Bendahara Desa, Kepala Seksi, dan Sekretaris Desa.

\section{Alokasi Dana Desa (ADD)}

Sesuai dengan Peraturan Pemerintah RI Tahun 2019 No.11 tentang Desa, alokasi dana desa adalah bagian dana perimbangan keuangan daerah dan pusat yang diperoleh kota/kabupaten untuk desa minimal 10\% (sepuluh persen), dengan pembagian untuk desa dengan secara proporsional.

Sesuai dengan Permendagri Tahun 2014 No. 114 mengenai Pedoman Pengelolaan Keuangan Desa dinyatakan bahwa ADD bersumber dari Anggaran Pendapatan dan Belanja Daerah kota/kabupaten yang berasal dari bagian dana perimbangan keuangan daerah dan pusat yang diperoleh kota/kabupaten untuk desa minimal $10 \%$ (sepuluh persen).

ADD (Alokasi Dana Desa ) Sesuai dengan UU Tahun 2014 No.6 mengenai Desa bagian dari dana perimbangan yang diterima kabupaten/kota paling sedikit 10\% (sepuluh persen) dari ABD sesudah dikurangi dana alokasi khusus. Berdasarkan Perda Kab. Muaro Jambi Tahun 2011 No. 16 mengenai Keuangan Desa bahwa anggaran pendapatan dan belanja desa berikutnya dinamakan APBDesa merupakan perencanaan keuangan desa per tahun yang disetujui dan dibahas BPD (Badan Permusyawaratan Desa dan pemerintah desa yang ditentukan Peraturan Desa. 
Berdasarkan definisi di atas, bisa ditarik kesimpulan bahwa ADD (Alokasi Dana Desa) adalah bagian keuangan desa yang didapatkan berdasarkan pembagian hasil pajak daerah dan bagian dari dana perimbangan keuangan daerah dan pusat yang diperoleh kota/kabupaten untuk desa yang dibagi secara proporsional.

Maksud ADD (Alokasi Dana Desa) yang menjadi bantuan keuangan oleh Pemkab pada pemerintah desa yang bersumber dari anggaran pendapatan Kabupaten, bertujuan mendanai kegiatan pembangunan desa untuk menjalankan aktivitas pemberdayaan masyarakat dan pemerintahan .

\section{Prinsip dan Asas Pengelolaan Keuangan Alokasi Dana Desa (ADD)}

Pengelolaan Keuangan ADD (Alokasi Dana Desa) adalah suatu integrasi yang melekat pada Pengelolaan Keuangan Desa pada Anggaran Pendapatan dan Belanja Desa. Dengan demikian dalam mengelola ADD wajib sesuai Prinsip Pengelolaan ADD antara lain: ${ }^{11}$

1. Semua aktivitas yang dibiayai ADD direncanakan, dijalankan, dan dilakukan evaluasi dengan cara transparan berdasarkan prinsip dari, oleh dan untuk masyarakat.

2. Seluruh kegiatan harus dapat dipertanggungjawabkan secara administratif, teknis dan hukum.

3. Alokasi Dana Desa (ADD) dilaksanakan dengan menggunakan prinsip hemat, terarah dan terkendali.

4. Jenis kegiatan yang akan dibiayai melalui Alokasi Dana Desa (ADD) sangat terbuka untuk meningkatkan sarana pelayanan masyarakat berupa pemenuhan kebutuhan dasar, penguatan kelembagaan desa dan kegiatan lainnya yang dibutuhkan masyarakat desa yang diputuskan melalui musyawarah desa.

5. Alokasi Dana Desa (ADD) harus dicatat dalam Anggaran Pendapatan dan Belanja Desa (APBDesa) dan proses penganggarannya mengikuti mekanisme yang berlaku.

\section{HASIL DAN PEMBAHASAN}

\section{Implementasi Alokasi Dana Desa Di Desa Mudung Darat Kabupaten Muaro Jambi}

Pengelolaan ADD (Alokasi Dana Desa) biasanya akan dimulai dengan sebuah aktivitas untuk menyusun rencana pada peningkatan pembangunan desa yaitu dengan cara mengikut sertakan banyak pihak yang berhubungan dengan desa yang biasanya ialah bagian dari suatu sistem perencanaan dalam membangun suatu wilayah. seperti dalam aktivitas pada permulaaan tahun yaitu persiapan Pelaksanaan Alokasi Dana Desa dengan penyusunan dan menginventarisir berbagai dokumen yang dibutuhkan sebagai persyaratan penerimaan alokasi dana Desa tahun 2016.

Sekitar tahun 2016 dalam melakukan suatu perancanaan Alokasi Dana Desa di Kabupaten Muaro Jambi masih sesuai Perda Kab. Muaro Jambi Tahun 2006 No. 08 mengenai Tata Cara Pembagian Dan Penetapan Rincian Alokasi Dana Desa. Alokasi Dana Desa tentang Petunjuk Teknis Pelaksanaan Alokasi Dana Desa di Kabupaten Muaro Jambi. Petunjuk Teknis Pelaksanaan ADD Kabupaten Muaro Jambi Tahun 2016 ini ialah penjabaran dari Perda Tahun 2006 No. 8 Tata Cara Pembagian Dan Penetapan Rincian Alokasi Dana Desa yang merupakan aturan selanjutnya terhadap sejumlah peristiwa yang yang berupa petunjuk secara teknis dan terperinci dalam pelaksanaan ADD.

Alokasi Dana Desa senilai $70 \%$ dipakai dalam melaksanakan aktivitas serta pembangunan terhadap orientasi desa berdasarkan dengan Raker Pembangunan Desa untuk tiap desa di wilayah yang sudah direncanakan serta diputuskan sesuai kesepakatan dengan mengutamakan pada program pemberdayaan masyarakat. Pengelolaan alokasi dana desa untuk semua aktivitas pemberdayaan masyarakat yang diselenggarakan dengan seluruh prinsip partisipatif, akuntabilitas serta transparansi. Partisipatif ialah sebuah rencana pengelolaan Alokasi Dana Desa disusun melalui mekanisme Perencanaan Partisipatif dan terdapat partisipasi dari masyarakat desa secara menyeluruh dalam setiap siklus pelaksanaan Alokasi Dana Desa. Transparansi ialah masyarakat bisa melihat secara terbuka semua informasi yang berhubungan dengan perencanaan, pengelolaan serta pelaporan Alokasi Dana Desa.

Biasanya dalam pembangunan fisik dan non fisik dibutuhkan keseimbangan dalam meraih maksud dan tujuan dari Alokasi dana Desa. Memfokuskan untuk pemberdayaan masyarakat serta meningkatkan layanan adminitrasi untuk mendapatkan perhatian, tidak hanya pembangunan fisik desa saja. Sesuai dengan perkembangan zaman, maka kualitas sumber daya manusia seharusnya ada peningkatan serta Alokasi Dana Desa sudah mengacu pada tingkatan akan mutu sumber daya manusia, yaitu dengan pemberdayaan masyarakat. Sebab dengan dengan memberdayakan masyarakat merupakan perencanaan yang sangat penting dalam kebijakan Alokasi Dana Desa, sebab pembangunan selama ini yang diutamakan hanya pembangunan dalam fisik, seperti membangun jembatan, pengerasan jalan, membangun gedung Taman Pendidikan Alquran (TPA) dan lain-lain yang didapatkan dan dipergunakan harus dapat dipertanggungjawabkan.

Sesuai wawancara dengan Kepala Desa Mudung Darat mengenai implementasi ADD dalam pemberdayaan masyarakat di Desa Mudung Darat mengatakan bahwa belum menjadi kebiasaan pemerintah desa dalam menjalankan program pemberdayaan masyarakat. Seluruh biaya biasanya akan dialokasikan untuk membangun dalam bentuk fisik, akan tetapi pada dana alokasi tahun 2020 ini akan di peruntukkan untuk membangun fisik akan lebih pada

\footnotetext{
${ }^{11}$ Kementrian Keuangan, Buku Saku Dana Desa, Direktorat Jenderal Kementerian Keuangan, Jakarta, 2017
} 
pembangunan pasar desa. Selanjutnya Alokasi Dana Desa yang ada akan dipakai dalam menjalankan aktivitas Kepemudaan, aktivitas PKK dan semua aktivitas yang ada di Desa. Dengan demikian, kebijakan program Alokasi Dana Desa di jalankan oleh Pemerintah Kabupaten Muaro Jambi dalam menyelesaikan permasalahan-permasalahn yang ditimbul di tengah masyarakat desa di Mudung Darat supaya ditemukan solusi yang tepat sesuai dengan regulasi seperti perundang-undangan, peraturan pemerintah, keputusan pejabat birokrasi dan keputusan lainnya termasuk perda, keputusan pejabat politik dan sebagainya. ${ }^{12}$

Sesuai wawancara dengan Ketua Lembaga Pemberdayaan Masyarakat di Dea Mudung Darat mengatakan bahwa rencana Kegiatan Anggaran Desa di Kecamatan Maro Sebo, pemakaian dana Alokasi Dana Desa pada pemberdayaan masyarakat desa yang ada dipakai sesuai alokasi ke beberapa pos yang sudah terencana yakni untuk aktivitas PKK, kepemudaan dan aktivitas lain-lain yang direncanakan. Rencana pemakaian Dana Alokasi Dana Desa dalam pembangunan Desa untuk satu periode ke depan sudah tercantum pada Rencana Kerja Pembangunan Desa biasa disingkat RKPDes. RKPDes sebagai hasil dari Musyawarah Perencanaan Pembangunan Desa (Musrenbangdes) yang diselenggarakan awal bulan tahun bersangkutan. Tim penggerak PKK Kecamatan Maro Sebo merupakan kader pembinaan untuk PKK pada beberapa desa di Kecamatan Maro Sebo. Berbagai kegiatan PKK bertujuan meningkatkan kesejahteraan keluarga, yang secara tidak langsung juga meningkatkan kesejahteraan masyarakat. Dalam penggunaan dana ADD, kegiatan PKK ini digunakan untuk pembiayaan kegiatan kesekretariatan dan belanja masing-masing Pokja. Masing-masing Tim Penggerak PKK dari beberapa desa di Kecamatan Maro Sebo setiap bulannya juga melaksanakan kegiatan kesehatan dan Posyandu, yang kegiatannya berupa kegiatan penyuluhan kesehatan, Posyandu, dan Perbaikan Gizi Anak dan Balita yang bekerjasama dengan Puskesmas di Kecamatan Maro Sebo. Dalam hal ini terlihat dari semangat dan kemauan Tim Penggerak PKK Desa dan Kader PKK di tiap- tiap desa benar-benar memanfaatkan dana yang berasal dari ADD. ${ }^{13}$

Selanjutnya Pemuka masyarakat desa Mudung Darat, memberikan keterangan bahwa pada pelaksanaan program ADD Tahun 2020, pembinaan anak dan remaja (Kepemudaan) dititik beratkan terhadap aktivitas serta pembinaan olah raga. Pengalihan anggaran menunjukkan pembinaan olah raga untuk belanja kostum sepak bola dan bola voli. Sementara itu, dalam peningkatan keahlian serta keterampilan olah raga, sehingga dibutuhkan fasilitas dan sarana prasrana yang dapat menunjang antara lain bola serta peralatan yang lainnya. Pada peluang alokasi dana desa ini, sehingga akan dibelanjakan bola untuk sepak bola, bola voli dan net. Dengan demikian pelatihan olah raga mampu mendorong serta memberi kegunaan serta manfaat untuk masyarakat ataupun bagi desa sendiri. Selain untuk kesehatan, aktivitas olah raga ini juga mampu menumbuhkan rasa kebersamaan dan kerjasama antar anggota masyarakat. ${ }^{14}$

\section{Kendala Dalam Implementasi Alokasi Dana Desa Di Desa Mudung Darat Kabupaten Muaro Jambi}

Dalam mengelola Alokasi Dana Desa pasti dijumpai berbagai kendala yang menghambat pelaksanaan kegiatan untuk mencapai tujuan. Sesuai wawancara dengan Ketua BPD Desa Mudung Darat, didapatkan hasil akhir yang menjelaskan berbagai kendala yang dihadapi pada Desa Mudung Darat sehingga menghambat implementasi ADD untuk memberdayakan masyarakat pada Desa Mudung Darat yaitu:

1. Minimnya wawasan Aparatur Pemerintahan Desa tentang fungsi dan Tugas Pokok dan minimnya informasi yang disampaikan

2. Mutu SDM (Sumber Daya Manusia) yang tidak menunjang aktivitas pelaksanaan dan Pengelolaan ADD

3. Tradisi Gotong Royong warga Desa yang memudar dan luntur Sosialisai Kepada Masyarakat ${ }^{15}$

Hambatan yang ada selama untuk proses alokasikan dana desa antara lain koordinasi dari Kecamatan yang masih kurang, Kantor BPMPDPKB dan DPPKAD Kabupaten Muaro Jambi persoalan mengenai SPJ (surat pertanggung jawaban), walaupun peraturan mengenai cara membuat SPJ (surat pertanggungjawaban) telah ditentukan. Akan tetapi dalam melaksanakan koordinasi yang masih kurang tepat terhadap instansi yang berkaitan sehingga dapat memberikan pengaruh terhadap kegiatan mengelola ADD dan bisa menghalangi berjalannya kegiatan itu pada program ADD itu, dengan demikian membuat kesulitan aparat desa. Dalam melaksanakan kegiatan Alokasi Dana

\footnotetext{
${ }^{12}$ Muhammad Ali, Wawancara dengan Kepala Desa Mudung Darat Kecamatan Maro Sebo Kabupaten Muaro Jambi, pada tanggal 20 Februari 2021

${ }^{13}$ Ilyas, Wawancara dengan Ketua Lembaga Kemasyarakatan di Desa Mudung Darat Kecamatan Maro Sebo Kabupaten Muaro Jambi, pada tanggal 20 Februari 2021

${ }^{15}$ Jamaluddin, Wawancara dengan Ketua Karang Taruna Mudung Darat Kecamatan Maro Sebo Kabupaten Muaro Jambi, pada tanggal 20 Februari 2021
} 
Desa tersebut, BPMPDPKB sebagai pelaksana kebijakan Alokasi Dana Desa dan tempat bertemu tim pengendali Alokasi Dana Desa dan Tim Pembina. Supaya penerapan kebijakannya efektif, maka wajib terdapat kerjasama yang baik antara Tim, contohnya melakukan verifikasi Anggaran Pendapatan dan Belanja Desa, dan membantu aparatur desa untuk menetapkan aturan desa mengenai Anggaran Pendapatan dan Belanja Desa dan yang terpenting ialah membina kegiatan mengelola Alokasi Dana Desa ini supaya sesuai dengan sasaran serta agar tidak menghambat dalam pertanggungjawabannya. Sebelum melaksanakan kegiatan Alokasi Dana Desa tersebut, maka secara intern harus dilakukan koordinasi dalam membuat perencanaan aktivitas, dengan demikian ketika melaksanakan penerapannya masing-masing personal telah paham akan tugas dan fungsinya.

Selanjutnya semua orang juga telah diberi bekal serta arahan melalui surat keputusan (SK). Sesuai banyaknya penjelasan memperlihatkan bahwa setiap individu yang berpartisipasi untuk proses penyelenggaraan kebijakan program Alokasi Dana Desa sudah mengetahui arah tujuan dari kebijakan program Alokasi Dana Desa. Peristiwa ini pasti didorong oleh mutu dari SDM tersebut dan kecakapannya untuk membuat kemitraan kerja antara personal yang saling berpartisifasi. Keadaan tersebut pastinya dapat mendorong akan kesuksesan dalam melaksanakan program.

Sesuai pada pengamatan serta hasil wawancara tersebut mendiskripsikan bahwa, setiap personal mempunyai tingkatan loyalitas yang tinggi pada penerapan program ataupun kebijakan. Hal ini menjadi keharusan sebab sebagai petugas, pada masing-masing pekerjaan yang diamanahkan seharusnya dilakukan dan didukung. Didapatkan informasi bahwa terdapat personil yang tidak dapat hadir maupun terjun langsung ke lapangan pada saat jadwal yang telah ditetapkan sebab megerjakan tugas utama, sebagaimana berdasarkan pihak DPPKAD, umumnya memiliki jadwal khusus contohnya penyusunan pertanggungjawaban keuangan kabupaten, melakukan verifikasi, melakukan pendataan SPJ setiap satuan kerja dan lain-lain. Apabila dianalisa berdasarkan pendapat tersebut, diduga bahwa telah dilakukan koordinasi yang baik di antara pelaksana kegiatan Alokasi Dana Desa, tapi bukan memiliki arti bahwa laporan SPJ Alokasi Dana Desa bisa dengan mudah tersampaikan kepada Pemerintah Desa. SPJ Alokasi Dana Desa yang yang mengalami kendala sepertinya tidak hanya diakibatkan koordinasi yang kurang maksimal untuk membina, namun bisa juga dkarenakan tindakan aparatur pemerintah desa yang lalai terhadap tanggungjawabnya.

Dari uraian diatas berdasarkan prinsip pengelolaan ADD, sebagaimana yang tercantum pada buku saku desa kementrian keuangan, khususnya di desa Mudung Darat ini, dapat disimpulkan bahwa semua aktivitas yang didanai ADD (Alokasi Dana Desa) direncanakan, dijalankan, dan dilakukan evaluasi secara trasnparan berdasarkan prinsip dari, oleh dan untuk masyarakat, hal ini telah dilaksanakan meskipun masih terdapat kendala pada respon masyarakat yang kurang tanggap terhadap hasil yang telah dievaluasi. Selanjutnya secara prinsip semua aktivitas harus bisa dipertanggungjawabkan secara hukum, administratif, dan teknis. Terhadap prinsip ini di Desa Mudung Darat khususnya masih kekurangan sumber daya aparatur desa yang memiliki kemampuan sesuai bidangnya. Sehingga secara administratif, kegiatan yang dilakukan dari ADD ini belum tersistematis baik secara teknis maupun secara administrasi. Hal tersebut juga berakibat pada pertanggungjawaban yang diaudit secara berulang-ulang dan sampai pada pendampingan oleh pendamping desa dalam penyusunannya. Di desa Mudung Darat ADD (Alokasi Dana Desa) dilakukan melalui penggunaan prinsip terkendali, hemat, dan terarah. Hal ini dapat terlihat pada setiap kegiatan program yang dilaksanakan. Namun pada prinsipnya bentuk aktivitas yang akan didanai dari ADD (Alokasi Dana Desa) sangat transparan dalam mengembangkan layanan publik dalam bentuk penguatan kelembagaan desam memenuhi kebutuhan dasar, dan aktivitas lain yang diperlukan warga desa yang ditetapkan dari musyawarah desa, belum sepenuhnya dapat dijalankan, karena pada saat dilakukan musyawarah desa, terjadi konflik kepentingan dari setiap usulan program. Hal ini juga di pengaruhi oleh keterikatan janji politik kepala desa kepada tim tim tertentu dan warga desanya. Sehingga pencapaian keputusan musyawarah terkadang terarah pada program yang bukan prioritas dibutuhkan.Selayaknya Desa Mudung Darat, kedepannya dapat menumbuhkan budaya partisipasi dari masyarakat yang terlibat dalam perencanaan dan pelaksanaaan program ADD terutama kaum pemuda yang merupakan generasi penerus guna memajukan desa dan membentuk desa yang mandiri, yang pada akhirnya mampu mengelola keuangan sendiri, dan mampu memiliki pendapatan desa sendiri tanpa harus terus dibantu dengan anggaran pemerintah daerah.

Masing-masing tahap dalam mengelola keuangan desa itu mempunyai peraturan-peraturan yang harus dimengerti dan dijalankan berdasarkan batas waktu yang sudah ditetapkan. Aktivitas dalam mengelola Keuangan Desa bisa dilakukan secara efektif yang harus didukung adanya SDM yang berkualitas dan berkompeten beserta prosedur dan sistem keuangan yang memadai. Untuk itu kemampuan desa yang mandiri dan kemampuan desa untuk mengelola keuangan desa adalah hal mendasar yang dimiliki kepala desa beserta perangkatnya. Beberapa upaya dari Pemda untuk memaksimalkan penerapan ADD (Alokasi Dana Desa) untuk meningkatkan hal tersebut dapat dilakukan melalui Sosialisai pada Warga desa, mengaktifkan kembali tradisi partisipatif ataupun gotong royong, memberi pelatihan dan keterampilan pada aparatur pemerintah desa pada pengelolaan ADD, dan memberi arahan mengenai prosedur dalam mengelola ADD. 


\section{SIMPULAN}

Sesuai dengan uraian yang sudah dijelaskan, dengan demikian bisa ditarik kesimpulan bahwa:

1. Tingkat pemahaman warga desa di Kecamatan sesudah adanya kebijakan ADD masih minim, mayoritas masih rendah. Hal ini dikarenakan minimnya pelatihan pada tenaga teknis oleh Tim Pengendali Kecamatan yang menyelenggarakan Pelatihan dalam mengelola Keuangan Desa dan Pelatihan pada Tenaga Teknis Aparatur Desa untuk mengelola Keuangan Desa, dengan demikian kegiatan dalam mengelola ADD terhadap belanja operasional dan belanja aparatur desa di Kecamatan belum terlaksana berdasarkan petunjuk ataupun peraturan yang tersedia. Implementasi pengalokasian Dana Desa untuk memberdayakan warga belum mengacu pada perkembangan sosial perekonomian warga Desa. Sebab faktanya ADD itu cenderung diutamakan ataupun diaktualisasikan dalam pembangunan fisik, akan tetapi pembangunan nonfisik sedikit yang didanai disebabkan Desa terlalu besar pembangunan fisik tidak tersedia, maka masyarakat mengutamakan anggaran yang besar untuk infratruktur. Dengan demikian kesimpulannya adalah dalam menjalankan pemberdayaan masyarakat dan Belanja Publik tidak terlaksana dengan optimal.

2. Kendala yang dihadapi dalam pengimplementasian alokasi yaitu minimnya wawasan ataupun pengetahuan aparatur Pemerintah Desa tentang fungsi dan tugas pokok dan minimnya sosialisasi dan penyampaian informasi pada publik. Mutu SDM (Sumber Daya Manusia) yang tidak menunjang pelaksanaan dan Pengelolaan ADD. Tradisi gotong royong warga Desa Mudung Darat yang sudah memudar dimana hal tersebut adalah keunikan tersendiri dari suatu Desa.

\section{DAFTAR PUSTAKA}

\section{Buku}

Azam Awang, Implementasi Pemberdayaan Pemerintah Desa, Pustaka Pelajar, Pekanbaru, 2010.

CST. Kansil, Kamus Besar Bahasa Indonesia, Bitra Indonesia, Medan, 2013.

Didik Sukriono, Politik Hukum Pemerintahan Desa di Indonesia, Jurnal Konstitusi Volume 1, PKK Universitas Kanjuruhan Malang, Malang, 2008.

Jefri S.Pakaya, Pemberian Kewenangan Pada Desa Dalam Konteks Otonomi Daerah, Jurnal Legislasi Indonesia, Volume 13 Nomor 01, 2016.

M. Muslih, Masriyani dan Ryanda Putra Pratama, Pelaksanaan Program Badan Usaha Milik Desa (BUMDes) Di Kecamatan Jambi Luar Kota Kabupaten Muaro Jambi, Jurnal Wajah Hukum, Universitas Batanghari, Volume 4, Nomor 2, Oktober 2020.

Nurcholis Hanif, Pertumbuhan dan Penyelenggaraan Pemerintahan Desa, Penerbit Erlangga, Jakarta, 2011

Peter Mahmud Marzuki, Penelitian Hukum, Kencana, Jakarta, 2009, Dalam buku Salim HS, Erlies Septiana Nurbaini, Penerapan Teori Hukum Pada Penelitian Tesis dan Disertasi, Cetakan ke-4, Raja Grafindo Persada, Jakarta, 2016

Soerjono Soekanto dan Mamuji Sri, Penelitian Hukum Normatif Suatu Tinjauan Singkat, Raja Grafindo Persada, Jakarta, 2010, hal. 14. Dalam buku Salim HS, Erlies Septiana Nurbaini, Penerapan Teori Hukum Pada Penelitian Tesis dan Disertasi, Cetakan ke-4, Raja Grafindo Persada, Jakarta, 2016

Sayogya, Sosiologi Pedesaan, Gadjah Mada University Press ,Yogyakarta, 2000.

Kementrian Keuangan, Buku Saku Dana Desa, Direktorat Jenderal Kementerian Keuangan, Jakarta, 2017.

Wasisitiono, Sadu dan Irwan Tahir.. Prospek Pengembangan Desa. Jatinangor: 2006

\section{Peraturan Perundang-Undangan}

Undang-Undang Nomor 23 Tahun 2014 Tentang Pemerintahan Daerah.

Undang-Undang Republik Indonesia Nomor 6 Tahun 2014 Tentang Desa.

Peraturan Pemerintah Republik Indonesia No. 11 Tahun 2019 Tentang Perubahan Kedua Atas Peraturan Pemerintah Tahun 2014 No. 43 Tentang Peraturan Pelaksanaan Undang-Undang Tahun 2014 No. 6 Tentang Desa.

Peraturan Menteri Dalam Negeri Tahun 2014 No. 113 Tentang Pengelolaan Keuangan Desa

Peraturan Daerah Kabupaten Muaro Jambi Tahun 2006 No. 08 Tentang Tata Cara Pembagian Dan Penetapan Rincian Alokasi Dana Desa 